ホモキラリティー

Homochirality

鏡像が元の像と重ね合わせることができない性質 をキラル（chiral）といい, 重ね合わせることがで きない鏡像体のことをエナンチオマー（enantiomer）とよぶ. ホモキラリティーとは，片方のエ ナンチオマーだけが存在している状態を指す. 夕 ンパク質は L-アミノ酸のみから, 核酸はD-(デオ キシ)リボースのみから構成されているというホモ キラリティーが生命世界の特徴である.

(180ページ)

（田村）

ヤング率

Young's modulus

物体に与えられたカとその力によって生ずる 歪みは比例する. この比例定数をヤング率という. 断面積（S）の物体に力（F）が加えられ，元の 長さ（L）が (dL) だけ伸びたとき, ヤング率 $\mathrm{E}$ は $\mathrm{E}=(\mathrm{F} / \mathrm{S}) /(\mathrm{dL} / \mathrm{L})$ で表される. ヤング率が小さい物体 ほど柔らかい.（182 ページ）

（岩楯）

\section{脂質 2 重膜の相構造}

Phase structures of lipid bilayer membranes

ゲル相の脂質 2 重膜は, アルキル鎖が密にパッキ ングされた秩序性の高い構造をもち, 周期的な波 打ち構造で特徵づけられるリップル相と滑らかな 表面をもつラメラゲル相の多形を示す. 密にパッ キングしたアルキル鎖の間にコレステロールが割 り込むと，ゲル相と比べて流動性は増大するもの の，秩序的な分子配列は保たれた秩序液体相が生
じる. スフィンゴ脂質とコレステロールに富む脂 質ラフトは，秩序液体相をとると考えられている.

(184 ページ)

(三浦)

線条体

Striatum

大脸基底核の構成要素の 1 つであり，被殼と尾状 核からなる. 被殼と尾状核は内包の発達によって 隔てられたもので，両者の間には互いに結合する 灰白質の線条が多数見られるため, 両者をあわせ て線条体とよぶ，運動機能や情動，認知などさま ざまな神経過程に関与している.

(186ページ)

（田中ら）

\section{分子認識}

Molecular recognition

分子間の非共有結合（水素結合，疎水結合など） を介して実行される, 分子の状態 (活性化, 不活 性化）の認識や分子種の認識などをさす. 状態認 識は反応 ON/OFF 制御などに関与する.

(192 ページ)

（日比野）

蛍光共鳴エネルギー移動

Förster resonance energy transfer (FRET)

蛍光分子 (ドナー) の発光スペクトルと他の蛍光 分子（アクセプター）の励起スペクトルに重なり がある際に, 両分子が近接し, かつ両分子の双極 子モーメントが適切な方向関係にあるとき, ド ナーの励起エネルギーがアクセプターを励起する 現象. (193 ページ)

（日比野） 